\title{
LIVING POSITIVELY WITH HIV/AIDS
}

\section{Geddes M Nala}

In 1985 my employer, Scaw Metals, appointed me as a candidate to attend a course as a non-departmental advisor. The course was run by the Department of Health and Population Development at their training centre in West Fort, Pretoria. The objective of the 2-week course was to train both departmental and non-departmental advisors in hygiene, high blood pressure, diabetes, family planning, obesity, STDs, communicable diseases and HIV/AIDS. After completing the course successfully, I would then impart the knowledge to my co-workers.

Together with the nursing sister who was in charge of our medical centre, we gathered as many teaching aids as we could lay our hands on. We borrowed a range of videotapes from Chris Hani Baragwanath Hospital and acquired audiovisual materials, booklets and posters from various health centres. We then played the self-explanatory videotapes on the medical centre TV for employees who had come to see the doctor, while they were waiting. We also conducted health sessions at the company's hostel after work.

Never did it dawn on me that I would be the carrier of the virus one day. Today I am living with HIV. The reason why I disclose my status is that I know what I am talking about. In 1999 I became very sick. I was losing weight drastically and always felt tired. I also had night sweats and was short of breath. I had 
become very thin and very dark. I ate very little and preferred fruit when I did eat.

During this time my younger brother phoned to inform me of the death of my elder sister's sister-in-law. The funeral would take place on the Saturday of that same week at the local Methodist Church at about 8 am, and we would leave for the cemetery at $1 \mathrm{pm}$. I left early on Saturday morning and arrived by $9 \mathrm{am}$. I did not see any of my family, as the church was jampacked, and it was only at the cemetery that I saw my younger brother and sister standing side by side. I went to join them, but to my surprise it took them longer than usual to recognise me. Tears began to roll down my younger sister's face.

I was driven home immediately after the funeral. My brother took me to the doctor, who examined me and, through a syringe, took two watery samples from my back (between the shoulderblades) and poured them into two small bottles. He told my brother that he suspected TB and warned him to take me and the samples to hospital no later than the following Monday. He then gave me treatment to help me through the weekend.

On Monday morning at the hospital, X-rays and further tests were conducted. I did indeed have TB. I was hospitalised, and further tests revealed that I was HIV positive; I only knew this through a counsellor before I was finally discharged. I want to give credit to this gentle lady and thank her, for after putting me at ease, she said, 'To be HIV positive is NOT A DEATH SENTENCE. You must read a lot about issues relating to HIV/AIDS. This will help you to cope with the situation, and if you find other problems, remind the virus - THIS IS MY BODY THAT YOU ARE LIVING IN. I WILL KICK YOU OUT IF YOU MISBEHAVE.' It really did the trick, and I believe contributed towards my acceptance of my situation. She was a true professional.

After this intensive and sincere counselling, she gave me a letter referring me to the clinic. I decided to take the letter to the company's medical centre for convenience. The doctor then referred me to another health centre, where further Xrays and other tests were done, before I was finally put on treatment. I was told that this treatment would last for 9 months.

I returned to work exactly 4 months later. The doctor recommended that I be put on a much lighter job. I then helped in the HR department with some filing and other personnel duties. After a few months I found a permanent position as a clerk in the Design and Development Department. Although I completed my TB treatment. I continued to fall ill from time to time. It would be pneumonia one day and influenza the next. I was in and out of hospital most of the time. My time-keeping also deteriorated. I could not sleep well because of night sweats and coughs. I would doze off at dawn and wake up late. I decided to disclose my status to my colleagues and boss. This required a lot of courage, but I had to do it. It would in turn relieve me of the stress of having to account for poor time-keeping and performance.

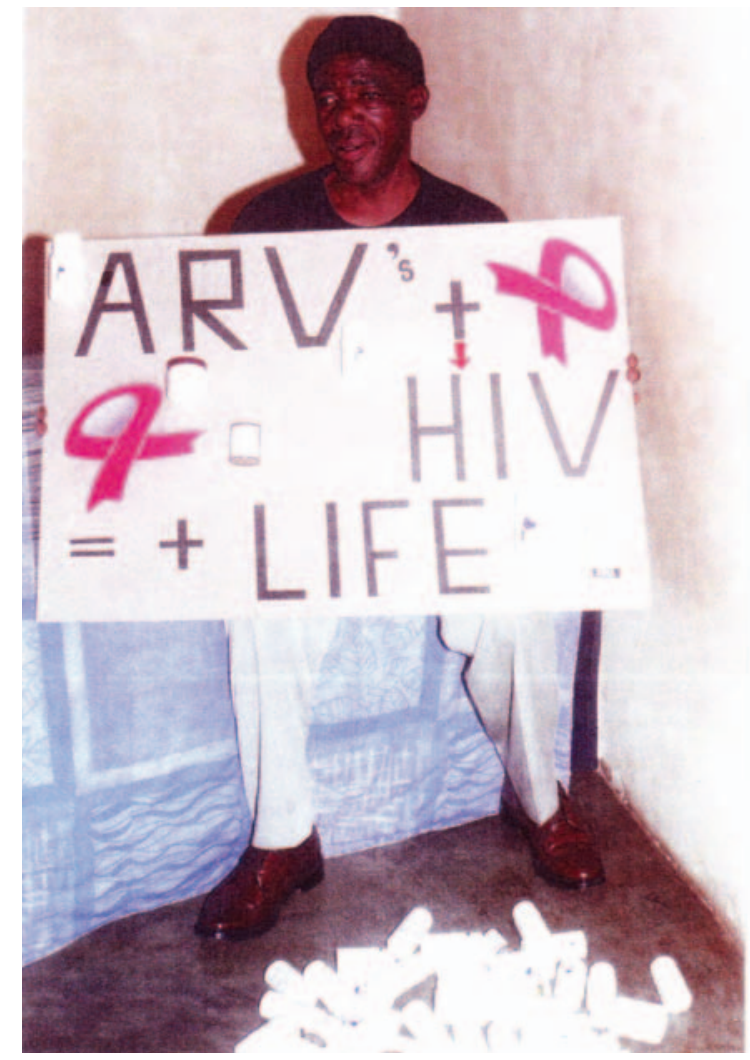

Word went around that the company would be rolling out ARVs in the near future. The doctor had informed me about it and had promised to put me on the ART programme once it was implemented. But when the clinic sister gave me the consent form to read and sign, I had chickened out and declined the treatment. I was not going to be a 'guinea pig'. I would not be the first one to experiment with a drug that had become so notorious for its toxic and other side-effects.

In 2003 I had to change my mind. In July I became so sick that everyone had written me off. I could not walk as much as 3 metres. I had lost a lot of weight. I was a skeleton and very, very dark. One would not even take a second look at me. I was finished ... The doctor informed me that I had pneumonia and referred me to hospital. There I was wheel-chaired to the consulting rooms and once examined, I was admitted immediately.

I was taken to Ward 2. There was something interesting about this ward. It looked like a club-house. All of the patients there looked exactly like me. They were very thin, very dark and every one was on a drip. Eventually when I sat on my bed I thought. 'Well this is a club all right, I just wonder which position I am going to fit into.' So much was happening in this ward: patients using food trolleys to carry them to the toilet, patients refusing to eat because of sores in their mouths, patients refusing to take a bath because of being powerless. Saddest was the mortality rate in the ward.

I do get along with my ex-wife, although we are divorced. I had phoned to inform her and my son that I was in hospital. She in turn passed on the message to my mom. She visited me often thereafter, bringing me food and prayers. She was also there when the rest of my family visited as well. I was having a good time. My niece had brought me food and fruit. As usual 
I was my jovial self and everyone was laughing. Then it was my sister's turn. She said, 'Geddes, my brother, you must get me correctly. I do not say that it will be like that, but there have been problems before. We are still struggling to sort out problems regarding my sister-in-law who recently passed away as we did not ask for her financial details while she was alive. Please understand we would not want to repeat the same mistake. Now, in case you die, where would you like to be buried? We would also appreciate it if you could provide us with your banking details and company benefits.'

Although it was not surprising, I did not expect it so soon. After taking a deep breath to settle down, I obliged and gave her the information and referred her to a friend and colleague for other benefits such as the NUMSA membership. Before they left, we said a prayer after which I accompanied them to their car and said goodbye. I returned to the ward and threw myself on my bed and my sister's words came back to me loud and clear, 'YOU ARE ABOUT TO DIE!' I jumped up and said aloud (to the surprise of other patients and nurses), 'NOT I, NOT NOW!'

On Friday in the second week of August I was discharged from hospital. I went straight to our medical centre and asked the sister to give me the consent form, and signed it. I did not have to waste time and read it now. I had nothing to lose. I had tasted death, so why not ARVs this time? Blood samples were taken and sent to the laboratory for analysis. After my final examination at the hospital, I was put on the ART programme on 28 August 2003. I have been on Combivir and efavirenz treatment ever since.

Before I took the treatment, my CD4 count was below 50 and my weight was below $40 \mathrm{~kg}$. I was dead, dead 'finish and klaar'. Today my CD4 count is well over 250 and my weight ranges between 73 and $76 \mathrm{~kg}$. I am healthy and strong. It is interesting to note that before I took the treatment I was treated for high blood pressure, but for unknown reasons since I started taking ARVs my BP is normal and I have been taken off its treatment.

What has actually prompted me to come out and talk is that I know what I am talking about. I felt guilty about remaining silent while other people were suffering and even dying from a situation that I had miraculously survived. I believed that it would haunt me until the last day of my life if I did not talk. That is why I appeal frankly and sincerely to all of you to go for VCT. Let our motto be 'TAKE ACTION NOW, KNOW YOUR STATUS:

The most dangerous thing about HIV/AIDS is the stigma. People refuse to go for testing for the following reasons:
Stigmatisation

- They are to afraid to know that they are HIV positive

They do not believe that there is such a thing as HIV/AIDS

They believe that HIVIAIDS is taboo

Culture and religion

Many years ago HIV-positive people were isolated and even killed.

There is nothing wrong with HIV/AIDS. A speaker once said, 'There are over 127 "viruses" like TB etc. and HIV is one of them. People prefer to admit that they suffer from TB or pneumonia rather than accept that they are HIV positive. Is it because the first two are curable, or is it because celebrities like or former state President Nelson Mandela and Bishop Desmond Tutu have publicly admitted to have been treated for $T B$, and it's not bad to suffer from what great men have once suffered from?

As Madiba himself once said, 'AIDS is no longer is a DISEASE but a HUMAN RIGHT'. We must put all the resources that we have together and intensify our fight against HIV/AIDS, just like we did in our Struggle against Apartheid. We must unite in the war against this pandemic in this country. We bury people who die from AIDS-related ailments daily. This is far above the statistics we receive through the media regarding the Middle East. What makes our battle even more complex is that it is abstract in nature.

Let us all go for VCT. This process is not time-consuming. Before testing you are put at ease through counselling, and after the test you are once more comforted. Your test results are strictly confidential. Your employer cannot force you to go for a test, and at the same time cannot victimise you for your status. If you test positive, do accept it, and leave with a positive attitude to your status. As one doctor said to his patient after testing positive, 'Two situations occur when you test HIV positive. The first one is that you deny and die long before you are buried. The second one is you accept and takr it as a wake-up call.'

It is therefore very important for us to encourage people to go for testing and know their status. We should convince them that being HIV positive is not a 'DEATH SENTENCE.' For those who test negative, we must encourage them to remain so by maintaining good lifestyles and practising protected sex.

In conclusion, I would like to thank my company for its compassion towards its employees. I would also appeal to other companies and public sectors to join in this campaign for the betterment of our country and all who live in it. 